\title{
ALTERNÂNCIA E DESEJO NA FEMINILIDADE E NA OBRA DE FRIDA KAHLO'
}

\section{Renata Wirthmann G. Ferreira Tania Rivera}

Resumo: O presente artigo apresenta uma articulação da teoria freudiana da feminilidade com a primazia do simbólico segundo Lacan, entrelaçado a considerações acerca da obra da artista plástica mexicana Frida Kahlo. Esse percurso tomou a feminilidade a partir do desejo e compreendida como algo completamente inserido no mundo simbólico.

Palavras-chave: Arte. Psicanálise. Frida Kahlo. Feminilidade. Desejo.

O maior apetite do homem é desejar ser. Se os olhos vêem com amor o que não é, tem ser.

Padre Antônio Vieira

A questão da Feminilidade sempre foi um enigma para Freud e é provável que, ao se perguntar"'O que quer uma mulher?",Freud já estivesse também propondo que, se o desejo sempre foi central na mulher, talvez fosse pelo desejo que se deveria tentar encontrar a mulher e, portanto, a própria sexualidade feminina. Uma sexualidade marcada por constantes alternâncias que dão à feminilidade um caráter de enigma

1 Esse artigo foi desenvolvido a partir da dissertação de mestrado de Renata Wirthmann Gonçalves Ferreira, intitulada "Máscara e Desintegração na Obra de Frida Kahlo: Das Bordas do Sentido ao Gozo Feminino", defendida em 2005 no Instituto de Psicologia da UnB sob orientação da Profa Dra Tania Rivera e com o apoio financeiro do CNPQ. 
que poderá ser buscado a partir do desejo não confessado, que sempre oculta algo para que o outro tente desvendar. Afinal, o desejo de um sujeito sempre encontra sentido no desejo do outro,"não tanto porque o outro detenha as chaves do objeto desejado, mas porque seu primeiro objeto é ser reconhecido pelo outro" (Lacan, 1998, p. 269).

O desejo feminino é um desejo por um falo e o falo é um objeto metonímico; sendo assim, podemos dizer que a feminilidade é, também, fundamentalmente metonímica. Podemos identificar, no desenvolvimento feminino, constantes alternâncias: alternâncias de objeto de amor, alternâncias de zona erógena e alternâncias entre atividade e passividade. Geralmente se consideram como características da feminilidade as preferências por fins passivos, entretanto, "para chegar em fins passivos, pode ser necessária uma grande parcela de atividade" (Freud, 1933/1996, p. 116).

A arte nos traz também a idéia de enigma, a partir do estranho que a comporta. Os diversos e simultâneos efeitos de estranheza experimentados por quem contempla uma obra de arte se confundem com algo que remete o contemplador a um objeto cotidiano, ou com algo inesperado que se apresenta a cada vez que se contempla uma mesma obra, ou com algo que nela permanecerá fixo, inalterado, cravando a atenção do contemplador, algo como um ponto que não se pode sequer circunscrever e que permanecerá sempre presente na relação de cada contemplador com uma mesma obra de arte.

Assim como a sexualidade, a feminilidade e a arte, a obra da artista mexicana Frida Kahlo fascina por suas constantes alternâncias. A obra de Frida Kahlo produz estranheza a partir da alternância de signos como os da feminilidade e da masculinidade, a partir das cores vivas e fortes que ela utiliza em suas telas para representar eventos dramáticos como um assassinato ou um aborto, ou, ainda, pelos elementos definidos por ela como sua própria realidade colocados numa organização quase onírica, ou ainda a possibilidade que Frida tem de transformar objetos inanimados, como, por exemplo, frutas, em auto-retratos, mas conservando as formas o mais próximo possível da sua referência natural.

\section{Ser ou não ser}

É da estrutura própria de um desejo buscar ser reconhecido simbólica ou imaginariamente. O princípio dessa busca de ser pode ser localizado no início do estágio do espelho, no momento em que a criança faz sua primeira identificação mediada pela imagem de um outro. Sob o signo da mediação os desejos se corporificam tal como o desejo de ter o próprio desejo reconhecido. Exatamente por isso, desde o início, "o desejo do homem se aliena no desejo do outro" (Lacan, 1998, p. 345). Nosso desejo se transporta para o desejo do outro, e esse transporte, que busca, no outro, 
o reconhecimento do próprio desejo, passa a ser mais importante do que aquilo que é desejado, mais importante do que o objeto do desejo.

$\mathrm{O}$ desejo feminino é semelhante ao desejo da criança pelo falo. $\mathrm{Ou}$ melhor, o desejo feminino é semelhante àquele desejo alienado da criança ao desejo da mãe, que é o falo. A criança busca satisfazer a mãe, e a forma que ela encontra é desejar ser o falo. A mãe deseja ter o falo, e a criança deseja ser o desejo da mãe, logo, ela deseja ser o falo da mãe. Em síntese, cada mulher pretende ser desejada e amada por isso que ela não tem.

A primeira relação da criança com esse desejo por um falo ocorre por meio de sua relação com a mãe, ou seja, durante a fase anterior ao Complexo de Édipo - segundo a teoria freudiana - ou o primeiro tempo do Complexo de Édipo - segundo a teoria lacaniana.

Essa fase, denominada pré-edipiana, possui uma organização imaginária e traz no próprio nome uma referência à fase que se segue. $E$ não poderia ser de outra forma, pois será somente depois de ter havido uma organização simbólica, característica do Édipo, que, retroativamente, o pré-Édipo ganhará sentido, sempre a partir da articulação significante do Édipo. Nessa perspectiva, o significante utiliza o significado para formar seu material. Então, será sempre num só-depois (nachträglich), no simbólico, que o passado, imantado de fantasias, poderá ser apreendido. Exatamente por isso, só depois, a fase pré-edipiana, prevalentemente imaginária, irá se estruturar simbolicamente na vida de cada sujeito.

Trata-se de uma fase em que não se verifica o reconhecimento da diferença anatômica entre os sexos e as descobertas de satisfação, pelas zonas erógenas, ocorrem de forma similar em meninos e meninas. Essas semelhanças iniciais do desenvolvimento das crianças levaram Freud a afirmar que"somos obrigados a reconhecer que a menininha é um homenzinho" (Freud, 1933/1996, p. 118). Isso equivale a dizer que não se nasce muIher, torna-se mulher durante um longo trabalho psíquico, e que, portanto, "a feminilidade é um vir-a-ser" (André, 1998, p. 191).

Nessa primeira fase do desenvolvimento sexual infantil, a criança deseja o desejo da mãe e ama a mãe, que assim se constitui seu objeto de amor, em função dos cuidados maternos que dela recebe desde o nascimento. Seu objetivo amoroso, em relação ao objeto de amor, está voltado para o lado ativo, amar. A zona erógena da menina, com sua entrada na fase fálica, passa a ser o clitóris - representante fálico na menina - e seu objeto de identificação é e não é o pai. Um pai que, nessa fase, não está necessariamente presente. Freud diz que, no pré-Édipo, o pai "é apenas um rival incômodo" (Freud, 1933/1996, p. 120), e será, por muito tempo, um estranho para a criança. Sua presença será, vez por outra, notada como a de alguém que incomoda a relação de exclusividade que a criança quer ter com a mãe. Prova dessa negligência ao pai e dessa exclusividade à mãe pode ser confirmada nas brincadeiras da menina com bonecas, quando estão presentes apenas dois personagens, mãe e filha. 
Durante a fase pré-edipiana, o objeto materno começa a ser reconhecido pela criança de forma alternada. Ora ele é mais, ora é menos; ora é ausência, ora é presença. E é daí, dessa alternância, que se origina a condição fundamental para o nascimento de uma ordem simbólica. $O$ apelo que a criança faz, reclamando a presença da mãe, indica o começo da instalação da ordem simbólica na articulação que a criança faz frente à presença-ausência da mãe. Assim, a mãe é chamada quando ausente e rejeitada quando presente, mediante uma vocalização. É nesse momento, com a participação da linguagem, que a mãe se transforma no primeiro Outro da criança.

A mãe, nessa primeira etapa, é tanto o Outro com o qual a criança experimenta suas primeiras simbolizações quanto o que promove a antecipação da lei.

É a mãe que vai e que vem. É por eu ser um serzinho já tomado pelo simbólico,e por haver aprendido a simbolizar, que podem dizer que ela vai e que ela vem. Eu sinto ou não sinto, o mundo varia com sua chegada e pode desaparecer. (Lacan, 1957-1958/1999, pp. 180-181)

Nesse primeiro momento, a criança é o objeto parcial e se pergunta o que querem dizer as idas e vindas da mãe. Se a mãe vai e vem caprichosamente, é porque, do ponto de vista do filho, ela deseja algo para além dele. Logo, esse ir e vir deixará claro para a criança que ela não satisfaz a mãe, que ela não é o objeto de desejo da mãe, ela não é o falo. Portanto, essas caprichosas idas e vindas representam o falo - aquilo que a mãe não tem e deseja ter - e a criança passa, então, a desejar ser o falo da mãe. Esse "é o desejo do desejo da mãe" (Lacan, 1957-1958/1999, p. 188), um desejo que se estabelece na relação da criança com o falo e que instaura a tríade imaginária mãe - criança - falo. O que é desejado na mãe está, portanto, para além dela mesma e se constitui justamente naquilo que lhe falta.

A questão da falta é um importante componente da obra de Frida Kahlo. O próprio início de sua obra parece marcar as origens dessa falta.

Em grande parte dos seus quadros, cartas e diário, Frida Kahlo aponta para um acontecimento de sua vida ao qual ela própria deu o estatuto de um marco fundador de sua obra, um acidente de automóvel: “Comecei a pintar há doze anos, ${ }^{2}$ quando me recuperava de um acidente de automóvel que me manteve na cama por quase um ano" (Kahlo, 2002, p. 105).

O acidente ocorreu em 17 de setembro de 1925, quando ela e seu namorado, Alejandro Gomes Arias, viajavam em um caminhão que bateu contra um bonde. Frida tinha 19 anos de idade e ficou gravemente ferida. Dentre as principais lesões, teve sua coluna vertebral rompida em três lugares na região lombar. Fraturou a clavícula e a terceira e quarta costelas. Teve onze fraturas na perna direita. Seu pé direito foi deslocado e esmagado. $O$ 


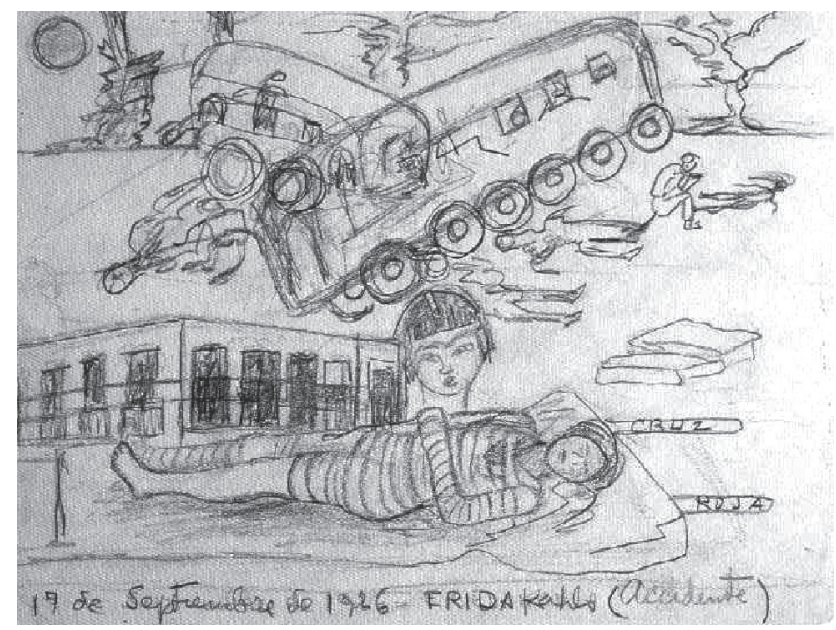

Figura 1.“O Acidente”, de 1926, Lápis sobre papel 20 × 27 cm.

ombro esquerdo ficou fora do lugar e a pélvis quebrou em três lugares. $O$ passamanes que atravessara o seu corpo, entrando pelo lado esquerdo do abdome, saiu-Ihe pela vagina."Perdi minha virgindade",ironiza (Kahlo, 1925, citado por Herrera, 2004, p. 74, tradução nossa).

Foi, fundamentalmente, devido ao acidente que Frida passou a ter uma saúde frágil, foi submetida a diversas cirurgias e nunca pôde ter filhos. Também após o acidente, Frida teve que passar um tempo acamada sem poder se movimentar. Eram poucas as coisas que Frida podia fazer, dentre elas pintar; sendo assim, Kahlo começou a pintar deitada em sua cama.

O primeiro quadro que Frida pintou, deitada em sua cama, foi um auto-retrato, em 1926, e para que ela pudesse servir de modelo para os seus quadros foram colocados espelhos em sua cama. Essa é uma importante influência para sua obra: a utilização dos espelhos para pintar sua imagem refletida.

Sobre a influência do acidente em sua obra, Frida diz nunca ter feito mais do que um esboço de quadro sobre o evento, pois, para ela,"o acidente foi muito complicado e importante, para reduzi-lo a uma imagem compreensível" (Kahlo, 1927, citado por Herrera, 2004, p. 102, tradução nossa). 0 esboço de que se trata é o desenho Acidente (figura 1), feito em setembro de 1926, um ano após o trágico evento. Temos, por esse comentário de Frida e pelo desenho, a transformação do acidente em ficção. Algo que, mesmo que apareça como imagem num quadro, não se resume a uma imagem compreensível ou a uma descrição de um evento biográfico. A obra de Frida ultrapassa o sentido primeiro da tela e, portanto, não é, jamais, completamente compreensível. 
A falta marca a teoria psicanalítica assim como marca a obra de Frida Kahlo. Não há amor sem falta. Numa relação amorosa o sujeito faz dom, ou seja, dá alguma coisa de maneira gratuita.

Lacan (1956-1957/1995) introduz o dom como "fórmula da pura gratuidade" (p. 143), no sentido de que o que se quer não é um bem possível, mas algo que só tenha valor como um signo de amor, ou seja, algo que ultrapassa o possível de ser dado, o nada, pois isso não se tem. Lacan diz, portanto, que amar não é dar o que se tem, mas sempre dar o que não se tem (p. 153). Adverte:"nada por nada é o princípio da troca” (p. 143). Então, sob tal perspectiva, o que a mãe dá para a criança, durante o primeiro tempo do Édipo, é considerado um objeto de dom, ou seja, aquilo que se dá de forma gratuita, na medida em que, por detrás do que se dá, existe tudo o que lhe falta,"é o que o sujeito sacrifica para além de tudo que tem"(p. 143). Não há demanda maior de amor do que a que exige algo que ultrapasse os limites do objeto amado. Exige-se algo para além do objeto amado, deseja-se não tudo o que aquele objeto tem, mas tudo o que ele não tem. "Não existe maior dom possível, maior signo de amor que o dom daquilo que não se tem" (Lacan, 1956-1957/1995, p. 142).

A mãe é fálica, mas a sua grande falta é a do falo. É aí que se localiza o amor da criança por sua mãe. Se a mãe fosse de fato plena, seria possível amá-la? Não há outra razão para amar a mãe, senão que, talvez, ela não tenha o falo.

Nessas relações de troca em que o falo é dom, o objeto em cena não é o pênis real, mas um falo simbólico, um falo que é tanto ausência quanto presença, em constante alternância, o qual não se possui. Trata-se do falo que aparece, desaparece e reaparece em diferentes lugares. Ou seja, aqui se está falando do "pênis na medida em que a mulher o tem - isto é, na medida em que ela não o tem" (Lacan, 1956-1957/1995, p. 154).

Em 1940, Frida pintou o quadro Auto-retrato com cabelo cortado. Nele, ela se apresenta sentada numa cadeira, com roupas masculinas largas e com uma tesoura na mão. Grandes mechas de cabelos pretos estão espaIhadas por todo o chão, pelo seu colo e sobre a cadeira. Na parte superior do quadro ela pintou o verso de uma canção mexicana: "Olha, se te amei foi pelo teu cabelo, agora que estás careca, já não te amo". Em grande parte dos seus quadros, Frida é pintada com vestidos tradicionais mexicanos, tehuana, com seus longos cabelos soltos ou em tranças e com alguns adereços como colares e brincos, entretanto, nesse quadro ela se veste com um terno masculino, tão largo que seria impossível dizer se é um corpo masculino ou feminino que se encontra por debaixo dessas roupas. Seus cabelos não aparecem simplesmente curtos, eles aparecem cortados pela tesoura que Frida segura e espalhados por todo o chão da tela. $O$ único adereço que permanece é o brinco, um elemento feminino.

Os cabelos chamam atenção desde a letra da música escrita na parte superior da tela até a forma como aparecem espalhados no chão, enrosca- 


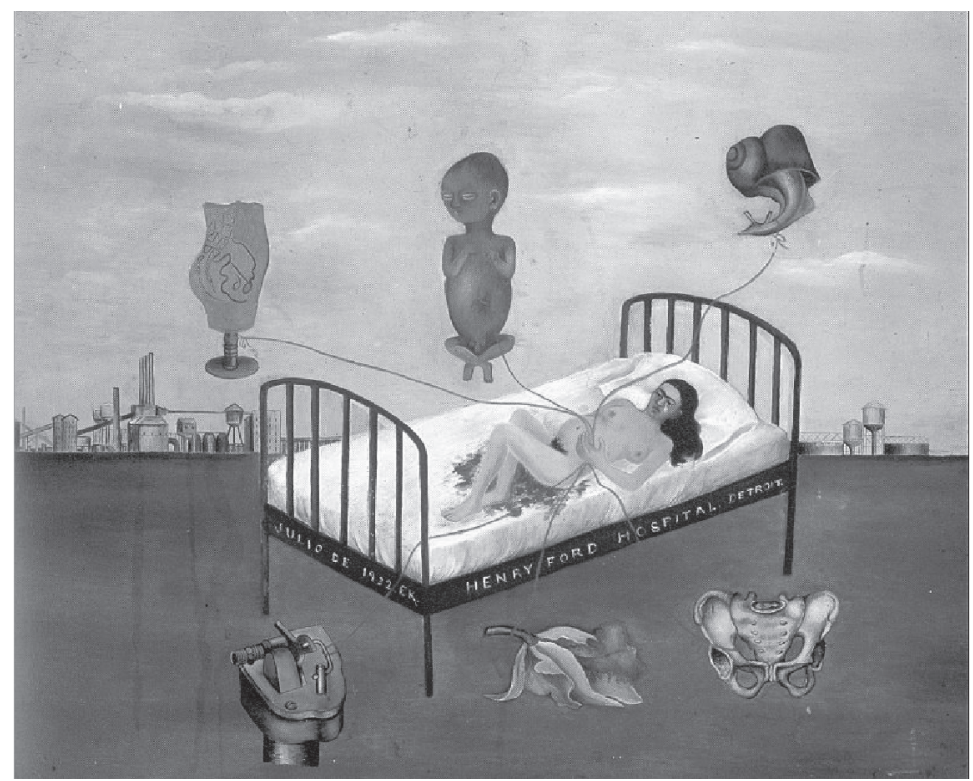

Figura 2. “O Hospital Henry Ford”, de 1932 Óleo sobre metal, 30,5 x 38 cm.

dos na cadeira e colocados sobre a perna de Frida. Devido a essa dimensão que é dada aos cabelos na tela, podemos dizer que os cabelos são tomados como significantes provisórios da sexualidade feminina: "Agora que estás careca, já não te amo". Há, nessa tela, o remetimento à perda e essa perda gera sofrimento pela possibilidade de uma segunda perda, que é a perda de amor.

Além dos cabelos, tomados, nesse quadro, como significantes da sexualidade feminina, outro elemento ganha esse mesmo estatuto no quadro O hospital Henry Ford (figura 2) ou A cama voadora. Neste, Frida aparece nua, toda ensangüentada, deitada numa cama de hospital, segurando seis fitas que parecem sair de seu corpo e que a ligam a seis elementos: a) um modelo anatômico do corpo humano da cintura à coxa; b) o osso da bacia; c) um feto, cuja fita se amarra a um pedaço de seu cordão umbilical cortado; d) um caracol; e) uma orquídea violeta; ef) uma peça de máquina que, juntamente com o cenário no fundo do quadro, faz referência a um lugar industrializado.

A peça de máquina e o fundo industrial são cinza, frios, distantes, e, somados a esse cenário, vemos uma pequena e frágil Frida, deitada no canto de uma cama enorme de hospital. Essa cama, em que Frida escreveu o nome de um hospital e de uma cidade, flutua no meio do quadro, no meio de uma paisagem limpa e pouco acolhedora. Não existem paredes, de modo que Frida, no quadro, está sozinha, sofrendo e completamente exposta. 


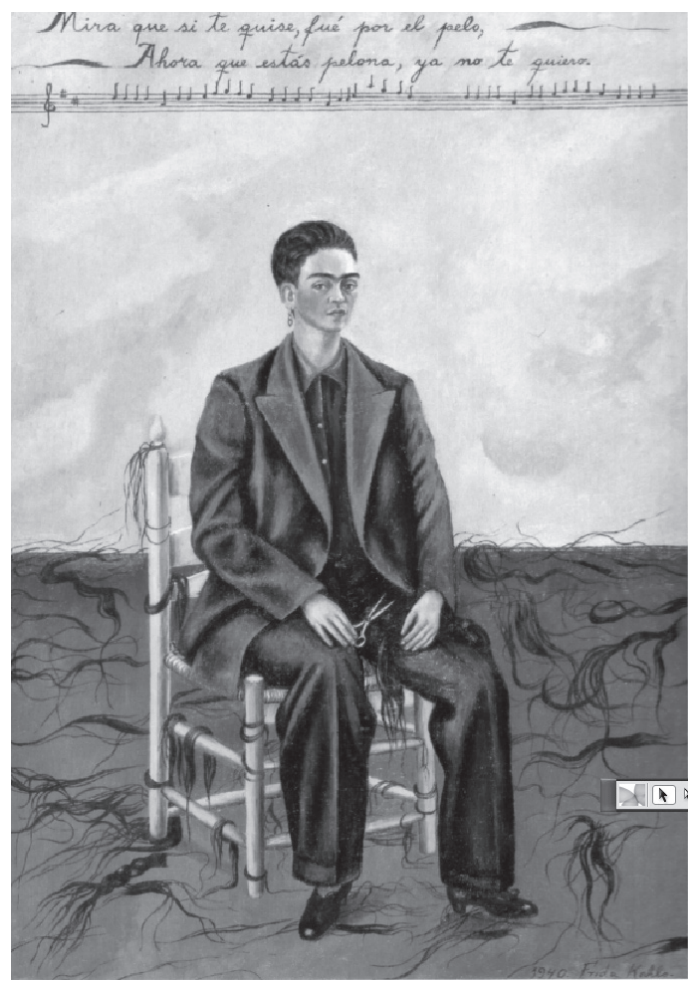

Figura 3. "Auto-Retrato de Cabelos Cortados", de 1940 Óleo sobre tela, $173,5 \times 173 \mathrm{~cm}$

Esse segundo quadro remete, mais uma vez, a sofrimento e perda. Os elementos amarrados estão escapando e ela tenta segurá-los com as mãos. O feto no centro do quadro é o feto abortado, o sangue sobre o lençol branco e sob Frida nos indica isso. Em outros quadros, além desse, Frida pinta um caracol ou uma concha como uma forma própria de representar a sexualidade feminina e a vida, o amor. Na descrição do quadro Moisés, pintado após ler o texto freudiano de mesmo título, ela diz:

No meio, na parte inferior, a coisa mais importante para Freud e muitos outros: 0 amor, representado pela concha e pelo búzio, os dois sexos [a concha o feminino e o búzio o masculino] envoltos pelas raízes eternamente novas e vivas. (Kahlo, 2002, p. 124)

Assim como no quadro Auto-retrato com cabelo cortado, o amor e a sexualidade são importantes elementos que marcam o quadro.

Nesse quadro a gravidez é tomada como outro significante provisório da feminilidade, e, assim como em relação ao cabelo, há uma perda, ou pelo menos é colocada em questão a possibilidade da perda a partir dos 
cabelos no quadro Auto-retrato de cabelos cortados (figura 3) e do feto no quadro O hospital Herry Ford. Mas o que seria essa perda?

Ora, a feminilidade é determinada por uma perda, que é, primordialmente, perda do falo. Essa perda não é sem efeitos para a menina e deixará traços em seu desenvolvimento. Se a menina é marcada pela ausência do falo, podemos afirmar que falta um significante para a sexualidade feminina. $O$ cabelo e o feto não são significantes da sexualidade feminina, apenas são tomados como semblantes, como significantes provisórios. Portanto, o cabelo e o feto não fazem suplência a essa ausência de significante e acabam sendo perdidos, como se perdeu o falo.

\section{Ter ou não ter}

Segundo Freud, na fase fálica, terceira fase do desenvolvimento infantil, após as fases oral e anal, ocorre a passagem da pré-história do Complexo de Édipo para o Édipo e o desenvolvimento do próprio Édipo. Quando a criança entra nessa fase - ou no que Lacan denominou como segundo e terceiro tempos do Édipo -, ocorre a descoberta da distinção anatômica, sendo que a diferença entre meninos e meninas está em ter ou não ter o pênis, pois não se reconhece a existência da vagina como órgão sexual.

Durante o segundo tempo do Édipo, a demanda que cada criança endereça ao Outro será encaminhada para o pai,"o Outro do Outro"(Lacan, 1957-1958/1999, p. 199), ou seja, o Outro da mãe que, por sua vez, era o Outro da criança no primeiro tempo do Édipo. Agora, o pai passa a ser também o Outro da criança. Isso só foi possível porque a mãe, antes, funda o pai como mediador daquilo que está para além de sua lei e de seu capricho - a Lei como tal. Somente por essa via o pai passa a ser aceito pela criança como aquele que, no plano imaginário, intervém como privador da mãe e dá suporte à Lei.

Assim, nessa etapa em que o pai passa a ser também o Outro da criança, o objeto de que a mãe depende - o falo -, deixa de ser apenas objeto de seu desejo e passa a ser um objeto que o Outro tem ou não tem. O pai"aparece menos velado do que na primeira etapa, mas não é completamente revelado", ele é mediado (Lacan, 1957-1958/1999, p. 209). E é exatamente devido ao fato de a proibição do pai incidir sobre o desejo da mãe que há a possibilidade de a criança não se tornar, pura e simplesmente, o desejo da mãe. Tudo isso acontece de forma transitória e rápida, mas é fundamental para que a criança se encaminhe para o terceiro tempo do Édipo, quando o menino sairá do Complexo de Édipo e a menina nele entrará.

Chegada, então, a terceira etapa do Édipo, aquilo que foi enunciado pelo pai, mediante o discurso da mãe, terá de ser mantido e cumprido. Agora não é mais a mãe quem tem o falo. É o pai quem o tem, e ele pode dá-lo ou recusá-lo - ainda que sempre esteja dando provas de que o tem. “É por [o pai] intervir no terceiro tempo como aquele que tem o falo, e não que o 
é, que se pode produzir a báscula que reinstaura a instância do falo como objeto desejado da mãe, e não mais apenas como objeto do qual o pai pode privar" (Lacan, 1957-1958/1999, p. 200). Dessa forma,"o pai pode dar à mãe o que ela deseja, e pode dar porque o possui" (Lacan, 1957-1958/1999, p. 200).

Na teoria psicanalítica a função do Édipo é normativa, ou seja, é função do Édipo que, no desenvolvimento, tanto da menina quanto do menino, seja instaurada a questão da genitalização. A entrada na fase fálica, em ambos, ocorre pelo reconhecimento da diferença anatômica. Durante o Édipo, ocorre a assunção do próprio sexo pelo sujeito, isto é, o homem assumirá sua virilidade e a mulher sua feminilidade (Lacan, 1957-1958/1999, p. 171). “Portanto, não basta que o sujeito, depois do Édipo, alcance a heterossexualidade, é preciso que o sujeito, moça ou rapaz, chegue a ela de forma tal que se situe corretamente com referência à função do pai. Aí está o centro de toda a problemática do Édipo" (Lacan, 1956-1957/1995, p. 206). Ao explicar a diferença entre a maturação genital masculina e a feminina numa dialética simbólica, Lacan afirma que a menina entra no Édipo porque não tem o falo e espera encontrá-lo no Édipo. Esse falo que ela busca é um elemento imaginário, tão exigente na ausência quanto na presença, mas marcado pelo sinal de menos. Ou seja, a menina entra no Complexo de Édipo com um sinal de menos, o que marca sua feminilidade, e o menino sai do Complexo de Édipo com um sinal de mais, o que marca sua virilidade, sua masculinidade (Lacan, 1956-1957/1995, pp. 124-125). Daí a importância da pré-história do Édipo principalmente para a menina, uma importância que somente será reconhecida a partir do Édipo, retroativamente (nachträglich).

Devido à importância daquela fase de ligação exclusiva da menina à mãe, as manifestações futuras da menina serão sempre determinadas "não por sua relação atual com o que sua mãe é hoje, mas pelas relações infantis com sua imagem mais antiga da mãe" (Freud, 1915/1996, p. 275). Assim, como a relação da menina com o pai foi construída de acordo com o relacionamento anterior dela com sua mãe, as futuras escolhas amorosas da menina serão uma herança do seu relacionamento original recalcado.

Em alguns quadros, lâminas e cartas da obra da artista plástica mexicana Frida Kahlo, vemos a construção de um amor ilimitado e possessivo, aos moldes do amor primitivo infantil, um amor que faz do objeto amado, filho, amante e ser fusionado a ela própria. Faz do objeto amado algo possessivamente seu, até que o pronome possessivo deixa de ser necessário, pois, mais do que pertencer a Frida, o objeto amado passa a ser ela mesma. Essa construção pode ser localizada na lâmina 60 do seu diário, que data, provavelmente, de 1947. Nela vemos, dentre outras que sempre começam com o nome Diego, as seguintes frases:"Diego meu menino," "Diego meu namorado,"“'Diego meu amante,"“Diego 'meu esposo',"'Diego meu amigo”, "'Diego minha mãe,"'Diego meu pai,','Diego meu filho,',Diego = eu" (Kahlo, 1996, p. 235). 
Entretanto, na lâmina seguinte do diário Frida questiona sobre a possibilidade dessa forma possessiva de amor e diz:"Por que o chamo de meu Diego? Nunca foi nem nunca será meu. Ele pertence a si mesmo" (Kahlo, 1996, p. 235).

Num texto intitulado "Retrato de Diego", de 1949, para o catálogo de uma exposição de Diego Rivera, artista plástico mexicano com o qual Frida Kahlo foi casada, Frida o descreve com um olhar minucioso. Chega a detaIhar sua forma e seu conteúdo, abordando, inclusive, seu romance com Diego. Nesse ponto ela fala sobre a possibilidade de sofrimento que poderia existir em sua relação com Diego:

Talvez vocês esperem que eu lamente "o quanto se sofre" vivendo com um homem como Diego. Mas não creio que as margens sofram por deixar o rio correr, ou a terra por causa da chuva, ou o átomo que descarrega sua energia...em minha opinião, tudo tem uma compensação mútua. Meu papel difícil e obscuro, de ser aliada de um ser extraordinário, tem a mesma recompensa de um ponto verde numa grande quantidade de vermelho: uma recompensa equilibradora. (Kahlo, 2002, p. 144)

Mas acaso há rio que possa existir sem uma margem que o delimite? Rio sem margem não é rio, é água que não corre, espalha-se sem rumo e chega a lugar nenhum. Margens moldam rios como o vaso molda o vazio. Um marca a moldura do outro. Nesse texto Frida mostra como um objeto de amor é moldado e molda quem o ama. Margem é tão objeto de rio quanto o rio é da margem. Um depende do outro, Frida e Diego.

Do mesmo modo, na arte ocorre esse movimento, de forma que não há obra sem artista e não existe artista sem sua obra, há sempre uma relação mútua.

A entrada da menina no Édipo, com um sinal de menos, ocorre devido ao Complexo de Castração, que é anterior ao Complexo de Édipo. É esse o momento em que não só o pai se afirma como portador do falo, mas, também, o momento em que o menino sai do Complexo de Édipo e a menina entra no Complexo de Édipo. Assim, a finalidade do Complexo de Castração é que "de um lado, o menino se transforme em homem, e de outro, a menina se transforme em mulher" (Lacan, 1957-1958/1999, p. 192). Se, para o menino, a dificuldade encontrada em seu desenvolvimento é a saída do Complexo de Édipo, para a menina, essa dificuldade se localiza em sua entrada no Complexo de Édipo. Tais dificuldades ocorrem devido ao Complexo de Castração, sendo que, no caso da menina:

Sua vida sexual é regularmente dividida em duas fases, a primeira das quais possui um caráter masculino, ao passo que apenas a segunda é especificamente feminina. Assim, no desenvolvimento feminino, há um processo de transição de uma fase para outra, do qual nada existe de análogo no homem. (Freud, 1931/1996, p. 236) 


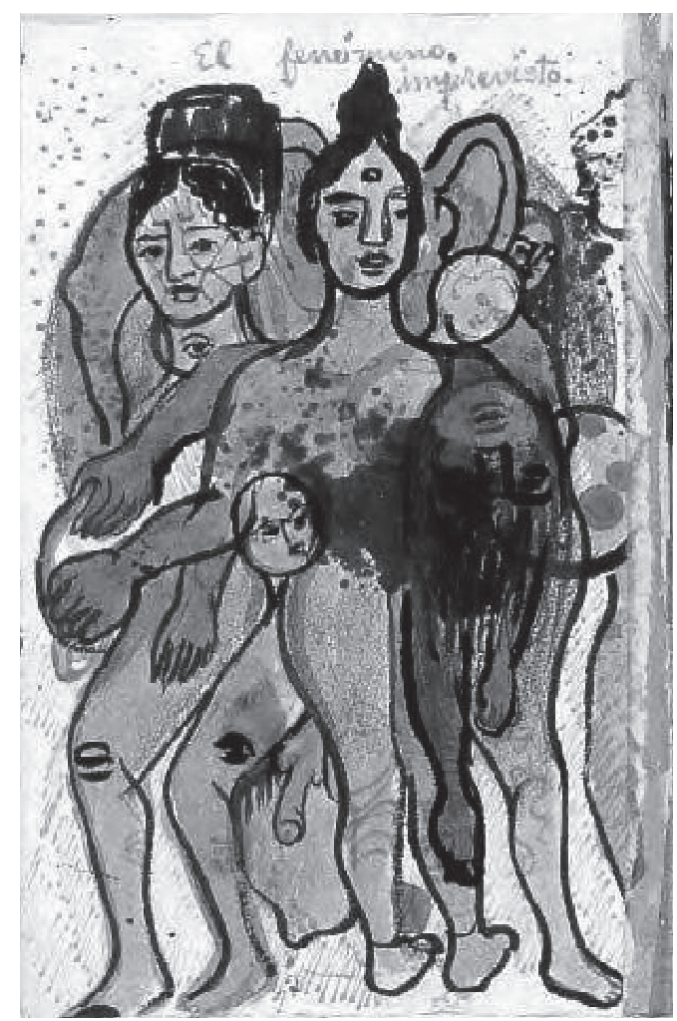

Figura 4. Lâmina 42: “O Fenômeno Imprevisto", de aproximadamente 1954 .

Além disso, se, por um lado, o primeiro passo do menino na fase fálica é a vinculação da masturbação às catexias objetais e a entrada no Complexo de Édipo, por outro, a primeira reação da menina frente ao sexo oposto é a descoberta de sua deficiência, sua falta, e a conseqüente inveja do pênis: "Ela viu, sabe que não tem e quer tê-lo" (Freud, 1925a/1996, p. 281).

Há, entretanto, uma hiância entre ver e saber que não tem. Por um momento, a menina tenta manter uma imagem do falo em seu corpo, um falo pequeno, escondido, mas que ainda poderia vir a se desenvolver. Essa defesa narcísica, de tentar manter o próprio corpo "inteiro", dura um breve instante, pois logo a menina perceberá que, de fato, não tem o falo e entrará no Complexo de Castração. Assim, ainda durante aquela segunda fase especificamente feminina, a menina troca de objeto de amor - a mãe pelo pai - e, conseqüentemente, de objeto de identificação - o pai pela mãe -, de objetivo amoroso - amar por ser amada -,e de zona erógena - o clitóris pela vagina.

A "inveja do pênis" ocorre, pois, graças ao fato de a menina reconhecer que ele Ihe falta. No entanto, ela não se adaptará a essa sua constitui- 
ção sem luta. Ela alimentará o desejo de possuir um pênis durante anos e, mesmo após haver percebido a impossibilidade de realizar tal desejo, ela continuará conservando consigo um grande investimento de energia no inconsciente.

Aquele breve instante em que a menina tenta manter em si a imagem do falo pode ser associado a uma imagem criada por Frida Kahlo e por ela denominada "Fenômeno imprevisto" (figura 4). Trata-se de uma aquarela do seu diário. Nela não se consegue distinguir nenhum corpo inteiro, o que se vê são figuras entrecortadas e sobrepostas, diversos olhos, orelhas, pernas, pés, braços, mãos e cabeças. No meio disso tudo, um pênis que parece pendular entre aquelas criaturas todas sem pertencer a nenhuma delas. Pêndulo que, talvez, por um breve momento, faça parte de uma ou de outra figura decomposta, deslizando sempre, sem pertencer unicamente a ninguém.

Na realidade, a importância do falo no Complexo de Castração da menina não está no fato de que ela própria não o ter, mas no de sua mãe não tê-lo podido dar a ela - simplesmente porque a própria mãe não o tem. Nesse sentido, o falo provoca uma dupla decepção para a menina:ele Ihe falta e falta à sua mãe.

"O falo não tem... o mesmo valor para aquele que possui realmente o falo, isto é, a criança masculina, e para a criança que não o possui, isto é, a criança feminina" (Lacan, 1956-1957/1995, p. 125). E isso faz com que os desenvolvimentos de meninos e de meninas tomem rumos distintos.

A possibilidade de ter ou de não ter o falo é o que está em jogo nesse momento. Mas se trata de um falo imaginário, do qual o menino terá que fazer dom, ou seja, dar provas de que não o possui para, de fato, o continuar possuindo. Ocorre que, frente ao pai, ele não o possuirá jamais. Portanto se a menina entra na simbólica do dom e também no Édipo por não ter o falo, o menino, por sua vez, sai do Édipo fazendo dom daquilo que tem.

Não ter o falo como órgão real faz com que a menina o tenha no plano simbólico, tenha-o enquanto um menos, uma ausência. Nessa representação da ausência do falo, a menina passa a poder ter o falo e o menino passa a poder perdê-lo. Assim, a esperança de ter o falo leva a menina ao Édipo, e o medo de perder o falo leva o menino à dissolução do Édipo.

\section{Não ter e desejar ter}

A partir da descoberta de sua própria castração, a menina, num primeiro momento, acredita que somente ela possui essa deficiência - reconhece a falta, porém, ainda não aceita a situação. Após essa etapa, a menina perceberá que tal infortúnio também atinge outras crianças. Posteriormente, ela localiza essa deficiência também em certos adultos, até que, por fim, descobre a castração da mãe (Freud, 1933/1996, p. 126). 
Nesse percurso da menina rumo à feminilidade, é necessário que ela abandone a mãe enquanto objeto de amor, tome-a como objeto de identificação e, ao mesmo tempo, tome o pai como objeto de amor.Paralelamente a esse movimento, ela deverá, ainda, abandonar o clitóris como zona de satisfação sexual e eleger a vagina como uma nova região de satisfação sexual.

A passagem de meninos e meninas pelo Complexo de Castração é permeada por obstáculos, muitos deles capazes de pôr fim à poderosa vinculação entre a mãe e a criança que perdurou durante todo o período préedipiano. No caso específico da menina, há fatores que, juntos, constituem o caminho pelo qual ela encontra a possibilidade de abandonar sua mãe enquanto objeto de amor.

Primeiramente, a menina acusa sua mãe de lhe ter dado pouco leite, ou seja, pouco amor. Depois, quando do eventual nascimento de um irmãozinho, todo o leite e cuidados da mãe são dirigidos para novo bebê, e esse movimento faz a menina odiar e ressentir-se contra a mãe infiel e contra o irmão intruso e rival. Além disso, a mãe foi quem, por meio dos cuidados de higienização, possibilitou à filha a descoberta da atividade masturbatória - e é também quem lhe proíbe essa atividade sexual fálica. A menina vê essa atitude da mãe como controversa e encontra aí mais um motivo para se rebelar contra ela. Como se não bastasse isso, a filha acusa a mãe pelo fato de, gerada por ela, ter sido colocada no mundo sem pênis, ou seja, ressente-se por ter nascido em desvantagem por culpa da mãe.

Mas isso não resume tudo. $\mathrm{O}$ amor infantil caracteriza-se como um amor ilimitado e, portanto, impossível. Dessa forma, a primeira relação amorosa da menina - aquela que ela estabelece com sua mãe - está destinada à dissolução: quanto mais se ama um objeto, mais a ele se devem desapontamentos e frustrações.

Por fim, notamos que o amor da menina estava dirigido à sua mãe fálica. Além daquelas censuras acumuladas contra a mãe, a menina descobre que sua mãe é tão faltosa quanto ela e, portanto, não poderia lhe proporcionar o pênis desejado.

Como, então, é possível, para a menina, tomar como objeto de identificação essa mesma mãe odiada?

"Todas as paixões se equivalem, todas são igualmente metonímicas" (Lacan, 1957-1958, p. 142). Portanto, se são metonímicas, são deslocamentos as passagens da mãe para o pai, do clitóris para a vagina. Na realidade, a mãe e o clitóris não serão jamais completamente abandonados, o pai nunca substituirá completamente a mãe e o clitóris continuará exercendo sua função erógena na vida sexual de uma mulher. Quanto à identificação com a mãe, Serge André diz que"para a menina a identificação com a mãe parece ser a condição pela qual seria possível não mais amá-la" (André, 1998, p. 185). Apesar de paradoxal, essa é a única maneira pela qual a menina pode se constituir sujeito e mulher. 
Sob tal perspectiva, pode-se concluir que a revolta apresentada pela menina contra a passividade, durante a fase pré-edipiana, numa luta pela atividade, tinha o propósito de expressar um desejo de separação. Dessa forma, paradoxalmente, "a menina deve abandonar a passividade para se destacar da mãe, mas deve também conservar esta passividade para se ligar ao pai" (André, 1998, p. 187).

A entrada da menina na dialética do Édipo se dá mediante ao substituto do pênis desejado - como se fosse ele uma criança que ela espera receber do próprio pai. A formulação inconsciente dessa equação simbólica vem daquilo que foi desviado na origem - ou seja, a mensagem da própria criança provém do pai sob uma forma invertida. $O$ desejo demandado ao pai na forma de Quero um filho teu, ou Terei um filho teu, é respondido mediante uma recusa pelo Outro paterno na forma de Não terás um filho meu, uma recusa que retorna à menina sob a forma invertida pelo imaginário, sendo recebida como uma promessa de amor do pai, Você terá um filho meu. Funda-se, assim, o Complexo de Édipo na menina.

Configurada, então, a promessa de que, simbolicamente, a menina poderá vir a ter o falo, ela entra no Édipo, assume o falo como instrumento da ordem simbólica das trocas e se confronta com uma outra ordem, a que tem o pai como figura central. Nessas circunstâncias, a menina participa de um engodo junto ao pai, um engodo no qual ela introduz a imagem da mãe como forma ideal do eu, num processo diferente do verificado durante a fase anterior, na qual a relação de engodo de que a menina participava era a estabelecida com a mãe. Dessa forma, a menina renuncia à demanda do falo no plano do amor objetal pela mãe para poder recebê-lo do pai como dom. É bom lembrar que o dom implica em um ciclo de trocas, uma imensa circulação de dons, surgida a partir de um mais-além da relação objetal. Nada é dom se não for constituído por uma revogação, porquanto aquilo que, num dado momento, viera ser objeto de dom teve que ser, antes, anulado. A menina só consegue, durante o Complexo de Édipo, deslizar de um pênis imaginário para um pênis real, numa equivalência simbólica rumo ao pai, porque o falo com o qual ela se relaciona, o falo que ela deseja e demanda, é o falo simbólico. Ninguém o possui, nem o pai. Sendo assim, simbolicamente, o desejo da menina por um falo direcionado ao pai nessa fase é também um desejo de algo para além do objeto de amor, é um dom.

Em seu diário, Kahlo escreve sobre a origem do quadro As duas Fridas. Nesse texto, de 1950, ela fala sobre uma amiga imaginária que ela tinha aos seis anos de idade:

$\mathrm{Na}$ janela do que então era meu quarto,... sobre um dos vidros mais baixos da janela eu soprava meu bafo. E com um dedo desenhava uma "porta". Por essa "porta eu saía na imaginação... onde "Minha amiga imaginária" estava sempre à minha espera. Não me lembro da sua imagem nem da sua cor. Sei, porém, que era alegre - que ria muito. Silenciosamente. Era ágil e dançava como se não 
tivesse peso nenhum. Observava os seus movimentos e enquanto ela dançava eu lhe contava os meus problemas secretos. Quais? Não me lembro. Mas minha voz bastava para que ela soubesse tudo de mim... Quando eu voltava à janela, entrava pela mesma porta desenhada no vidro. Quando? Durante quanto tempo havia estado com "ela"? Não sei. Podia ter sido um segundo ou milhares de anos... Eu era feliz. Apagava com a mão o desenho da "porta" e "desaparecia". Corria meu segredo e minha alegria até o recanto mais afastado do pátio de minha casa. (Kahlo, 1996, p. 246, itálicos nossos)

Nessa brincadeira que Frida criou dentro de um mundo que ela diz ser seu, ao qual ela tem acesso por uma porta desenhada no embaçado de um vidro, ela faz uma descrição de sua relação com uma amiga imaginária que é a descrição de algo que está para além do objeto, numa possibilidade de um feliz encontro consigo mesma, menina. Frida Ihe contava seus problemas secretos, "Quais? Não me lembro,"'Quanto tempo havia estado com 'ela'? Não sei?","Eu era feliz", nada disso importava "minha voz bastava para que ela soubesse tudo de mim".

Não importava a imagem do objeto, ou quais eram os problemas que Frida Ihe contava ou quanto tempo ela ficava com sua amiga imaginária, o importante é que ela estava sempre à espera de Frida e isso a fazia feliz, fazia com que ela corresse com "grande alegria e muita pressa" (Kahlo, 1996, p. 245) ao encontro que Frida descreve como mágico. Essa amizade imaginária se passa em um mundo próprio em que não há falta, a amiga está sempre lá, os problemas são irrelevantes e o tempo inexiste. A relação entre Frida e sua amiga é de uma lógica imaginária em que é possível encontrar uma harmonia plena, em que a amiga imaginária é tomada como um objeto narcísico, afinal:"o Imaginário é uma armadilha que prende o sujeito em uma imagem de si vinda do outro e em uma imagem do outro vinda de si. A comunicação do eu com o outro sempre se desenrola em uma casa de espelhos" (Safatle, 1997, p. 129).

Essa relação de Frida com sua amiga imaginária é análoga àquela, apontada por Lacan no Seminário 4 (1956-1957/1995, p. 68), em que a criança está presa numa relação fundamentalmente imaginária. Nesse momento, didaticamente hipotetizado por Lacan, a relação da criança com a mãe é estruturada como se fosse possível uma relação plena, em que a criança tem fome, chora e a mãe vem; saciada, ela chora de novo e a mãe vai embora - uma relação perfeita, ou seja, movida exclusivamente pelo capricho da criança, como a relação de Frida com sua amiga imaginária. Nessa relação imaginária, não está presente a relação simbólica mediada pelo objeto de dom.

O objeto de dom é, para a menina, o falo que, sem pertencer todo o tempo e de forma exclusiva nem à mãe e nem ao pai, é um objeto metonímico. Num primeiro momento, a partir da visão de meninos e de meninas, ele estava com a mãe, depois passou ao pai. O pai passa a ser, então, o porta- 
dor do falo - e é justamente por ter o porte do falo sem o possuir definitivamente que o pai terá sempre que dar provas de que realmente o possui.

Todo pai foi antes um menino que teve que, em primeiro lugar, reconhecer e assumir que não podia ter o falo, quer frente ao seu pai, quer frente à sua mãe, para só depois poder tê-lo frente a uma outra mulher e a seus filhos, se esse for o destino do seu Complexo de Édipo. De modo semelhante, toda mãe foi antes uma menina que desejou se fazer amada pelo pai, na posição passiva. Porém, para poder se dirigir ao pai, foi necessário que ela conservasse uma parcela de atividade, característica da fase pré-edipiana.

Essa situação vivida por meninas retrata a diferença fundamental entre ser amada e se fazer amada. Em Lacan vê-se que a mulher se faz imagem com um caráter cativante e com certa parcela de exibição. Há, portanto, na feminilidade, sucessivas alternâncias entre atividade e passividade, e nisso está o caráter metonímico de seu desenvolvimento.

"O objeto metonímico é fragmentado, se o objeto metonímico se quebra tão bem, é porque, como objeto metonímico, ele já não passa de um fragmento da realidade que representa" (Lacan, 1957-1958, p. 43). As características presentes em homens e mulheres que denotam atividade e passividade são, portanto, fragmentos da masculinidade e da feminilidade que funcionam como objetos metonímicos.

No entanto, mesmo que a feminilidade seja fundamentalmente metonímica, há, sem dúvida, algo de metafórico em seu desenvolvimento, caso contrário, não haveria desenvolvimento algum.

O que há, então, de metafórico e metonímico na feminilidade? Lacan (1957-1958/1999, p. 180) diz que o pai é uma metáfora, ou seja, ele não é nem objeto real, nem objeto ideal: ele é simbólico. Portanto, o pai é, na dialética simbólica, uma metáfora, ou seja, um significante que substitui outro significante - a mãe. A mãe, por sua vez, nessa mesma dialética, vai e vem, deslizando sempre e, conseqüentemente, não é completamente substituída, sendo que a resposta para suas idas e vindas é, justamente, o falo. Como isso é possível? Como dizer que o pai é metáfora, mas não substitui completamente a mãe? Percebemos, então, que na incidência do nome do pai na entrada da menina no Complexo de Édipo vai haver uma dupla via:algo de metonímico e algo de metafórico. Parte da subjetividade da mulher é barrada pela metáfora paterna, a fim de que ela não retorne à mãe, enquanto uma outra parte dessa mesma subjetividade permanece em trânsito metonímico:

Se a função do pai consiste em introduzir o sujeito na lei do falo, e se este significante do falo é insuficiente, por definição, para significar aquilo que seria a feminilidade propriamente dita, o resultado é que a significação induzida pela metáfora paterna fica sempre incompleta, insuficiente para atribuir a um sujeito seu lugar de mulher. (André, 1998, p. 181) 


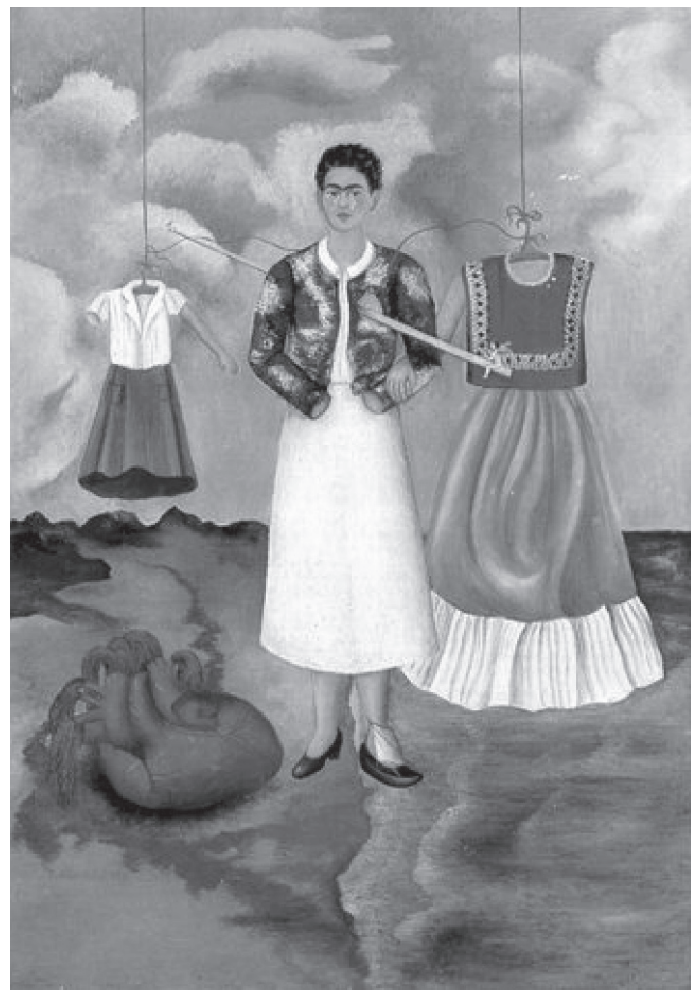

Figura 5. “Recordação”, de 1937, Óleo sobre metal, $40 \times 28 \mathrm{~cm}$.

Assim, dentro de uma relação metonímica, a menina, na medida em que assume, no primeiro tempo do Édipo, o desejo da mãe - ser ou não ser o falo - e se inscreve no lugar da metonímia da mãe, transforma-se em assujeito. Enquanto isso, numa relação metafórica, dá-se o Complexo de Castração, no qual substituições terão que ser feitas. Entretanto, mesmo que o Complexo de Castração seja uma relação metafórica, o resultado dele na menina é metafórico e metonímico, na medida em que, assim como sua mãe, ela também viverá apenas parcialmente no mundo simbólico, enquanto que parte do seu desejo permanecerá no plano imaginário.

\section{O enigma da feminilidade}

Tornar-se mulher, para Freud, é tornar-se mãe."Freud atribui ao filho o papel de significante da identidade feminina" (André, 1998, p. 198), sendo que ele atribui valores diferentes à satisfação materna quanto a ter um filho ou uma filha:"A mãe somente obtém satisfação sem limites na sua relação 
com seu filho menino; este é, sem exceção, o mais perfeito, o mais livre de ambivalência de todos os relacionamentos humanos" (Freud, 1933/1996, p. 132).

Lacan diz que essa descoberta freudiana coloca a mulher numa posição subordinada. A menina foi conduzida ao pai por sua falta, pela falta no seu objeto primitivo de amor, numa busca de satisfação com "o objeto da relação natural de procriação" (Lacan, 1956-1957/1995, p. 207). Após essa etapa de amor com o pai, a menina só terá que esperar pacientemente pelo substituto do pai, que lhe dará efetivamente uma criança, desempenhando o mesmo papel que fora antes da mãe e depois do pai.

Lacan propõe que essa posição de subordinação caracterize o supereu feminino. Para Freud, o supereu é o herdeiro do Complexo de Édipo, mas, como nas meninas não há propriamente uma dissolução do Édipo pois falta um motivo como foi, por exemplo, o Complexo de Castração nos meninos -, o estabelecimento do supereu feminino se dá, provavelmente, como resultado da criação e da intimidação que, provenientes do meio simbólico, ameaçam a menina com a possibilidade de perda de amor.

Em 1937, Frida pintou o quadro Recordação (figura 5). Nessa tela, um cabo de madeira atravessa seu corpo à altura do coração - um coração que se encontra aos seus pés, em tamanho desproporcional, com sangue saindo e escorrendo pela areia afora, até o mar e as montanhas. As ondas do mar lavam o sangue fazendo com que ele se dilua completamente e desapareça. O cabelo de Frida está curto e ela está sem os braços. Um rasgo pintado na tela chama a atenção para os seus pés. Eles aparecem calçados por sapatos diferentes, sendo que um pé está com sapato de salto enquanto o outro está com uma sapatilha.

$\mathrm{O}$ rasgo desenhado na tela sugere que, ao mesmo tempo que ele vela o pé, escondendo algo, ele o evidencia, nos leva a fixar a atenção, de forma que, ao tentar velar algo, produz-se o efeito contrário de nos atentar ainda mais para o que se buscava esconder. O pé rasgado, barrado, é, portanto, paradoxalmente reforçado, mostrando sua importância como significante recalcado.

A possibilidade de retorno do recalcado só é possível porque o representante pulsional recalcado continua a existir no inconsciente, onde se organiza, estabelece ligações e origina derivados (Freud, 1915/1996, p. 153). Freud afirma que o recalcado se prolifera no escuro, exercendo pressão contínua em direção ao consciente e podendo, ainda, retornar, mesmo que momentaneamente, através dos sintomas, sonhos, chistes, na fobia, na histeria etc.

Em Recordação, atrás de Frida, há um cabide e, dependurado nele, uma roupa colegial, de uma menina, provavelmente sua, pois guarda um de seus braços que Ihe faltam na figura central. Ao lado de Frida vê-se, também pendurado num cabide, um vestido tehuana, com o qual ela aparece em muitos de seus quadros. Esse vestido tem o outro braço de Frida, e está bem mais próximo dela, amarrado por uma linha vermelha à roupa colegial. 
A possibilidade que o rasgo da tela nos trouxe para falar em retorno do recalcado aparece também nas roupas penduradas. $O$ buraco no peito de Frida nos leva a perceber que a linha vermelha, que liga os dois cabides, passa por dentro dela, através desse buraco.Um acontecimento imprevisto, o pedaço de pau, retirou o coração de Frida do caminho e possibilitou que essa linha passasse por aí. O vestido colegial e o vestido tehuana podem ser tomados como imagens fixadas no tempo, um tempo que é evanescente, que dilui marcas, como as ondas do mar. Recordação, algo não se dilui completamente no tempo e continua participando de Frida na tela. Algo é recordado a partir da construção que se fez de um determinado momento que foi capturado e transformado em linguagem, imagem.

A feminilidade é marcada pela alternância e pelo desejo. A situação edipiana resulta de uma evolução longa e difícil que trará, para a menina, a possibilidade de descanso, de refúgio. Ela não mais vive o temor da Castração e vê aproximar-se o período de latência. Sem ter um motivo que a conduza ao fim do Complexo de Édipo feminino, a menina permanecerá nessa posição por um tempo indeterminado sendo que, posteriormente, tal complexo poderá apresentar três resultados: "ele pode ser lentamente abandonado ou lidado mediante o recalque, ou seus efeitos podem persistir com bastante ênfase na vida mental normal das mulheres" (Freud, 1925a/1996, p. 286). Ou seja, jamais o Édipo é completamente destruído. Ele sempre fará parte do futuro da mulher. Sendo assim, o desejo que a menina tem de receber um filho do pai está fadado a ser irremediavelmente frustrado, restando, depois, a ela dirigir sua demanda a um substituto paterno, um homem.

A feminilidade é um problema da sexualidade como um todo e traz questões para todos, inclusive a própria mulher. Talvez porque a própria teoria da castração freudiana, sobre a feminilidade, contribua para a manutenção desse mistério, "a teoria é ao mesmo tempo máscara e reveladora do objeto que visa" (André, 1998, p. 205).

Em conseqüência, se quisermos avançar nessa questão da feminilidade, para além do ponto até onde Freud a levou, é preciso questionar inicialmente o que faz com que a feminilidade seja um enigma, e o que poderia nos induzir a cultivar semelhante enigma, em vez de resolvê-lo. Talvez a vida do ser falante dependa de que não se levante o véu que encobre este mistério. É isso, pelo menos, o que deixam pensar os discursos, tanto de homens como de mulheres, sobre o que é e sobre o quer uma mulher. (André, 1998, p. 205)

Tomando o desejo como central na feminilidade, Lacan chegou às mesmas conclusões freudianas e, considerando-as insuficientes, iniciou uma busca de um novo modo de abordar a feminilidade, para além da castração, para além do simbólico. Essa busca irá culminar numa relação do feminino não mais com o simbólico, mas com o Real; não mais com o desejo, mas com o Gozo. 
A questão o que quer uma mulher? aponta, justamente, para o desejo como central na teoria freudiana e, portanto, como central nessa primeira elaboração freudiana acerca da feminilidade. Entretanto, em Lacan, o desejo perderá esse estatuto ao longo de seus Seminários e sua teoria tomará o Gozo e o Real como o centro de suas elaborações.

\section{Alternation and desire in the femininity and in Frida Kahlo's work}

Abstract: The present article presents a joint of the freudian theory of the femininity with the priority of the symbolic according to Lacan, intertwined with consirations on the work of Mexican plastic artist Frida Kahlo. This journey took the femininity beginning on desire and comprehended as something which is completely inserted in the symbolic world.

Keywords: Art. Psychoanalysis. Frida Kahlo. Femininity. Desire.

\section{Alternance et désir en la feminilité et dans l'oeuvre de Frida Kahlo}

Résumé: L'article réalise une articulation de la théorie freudienne de la féminité au primat du symbolique selon Lacan, tout en l'entrecroisant à des considérations sur l'oeuvre de l'artiste plastique méxicaine Frida Kahlo. Ce parcours prend la féminité comme centrée par le désir et la comprend en tant que complètement insérée dans le monde symbolique.

Mots-clés: Art. Psychanalyse. Frida Kahlo. Féminité. Désir.

\section{Alternancia y deseo en la femineidad y em la obra de Frida Kahlo}

Resumen: El presente artículo presenta una articulación de la teoría freudiana de la femineidad con la primacía del simbólico según Lacan entrelazado a consideraciones cerca de la obra de la artista plástica mexicana Frida Kahlo. Ese recorrido ha tomado la femineidad a partir del deseo y comprendida como algo completamente insertado en el mundo simbólico.

Palabras-clave: Arte. Psicoanálisis. Frida Kahlo. Femineidad. Deseo. 


\section{Referências}

André, S. (1998). O que quer uma mulher? Rio de Janeiro: Jorge Zahar.

Freud, S. (1996). Três ensaios sobre a teoria da sexualidade. In Edição standard das obras completas de Sigmund Freud (Vol. 7, pp. 119-228). Rio de Janeiro: Imago. (Trabalho original publicado em 1905)

Freud, S. (1996). Sobre as teorias sexuais das crianças. In Edição standard das obras completas de Sigmund Freud (Vol. 9, pp. 189-204). Rio de Janeiro: Imago. (Trabalho original publicado em 1908)

Freud, S. (1996). Conferência XXI: o desenvolvimento da libido e as organizações Sexuais. In Edição standard das obras completas de Sigmund Freud (Vol. 16, pp. 325-342). Rio de Janeiro: Imago. (Trabalho original publicado em 1916)

Freud, S. (1996). O estranho. In Edição standard das obras completas de Sigmund Freud (Vol. 17, pp. 235-273). Rio de Janeiro: Imago. (Trabalho original publicado em 1919a)

Freud, S. (1996). Uma criança é espancada: uma contribuição ao estudo da origem das perversões sexuais. In Edição standard das obras completas de Sigmund Freud (Vol. 17, pp. 193-219). Rio de Janeiro: Imago. (Trabalho original publicado em 1919b)

Freud, S. (1996). A psicogênese de um caso de homossexualismo numa mulher. In Edição standard das obras completas de Sigmund Freud (Vol. 18, pp. 157-185). Rio de Janeiro: Imago. (Trabalho original publicado em 1920a)

Freud, S. (1996). Além do princípio de prazer. In Edição standard das obras completas de Sigmund Freud (Vol. 18, pp. 13-75). Rio de Janeiro: Imago. (Trabalho original publicado em 1920b)

Freud, S. (1996). O ego e o Id. In Edição standard das obras completas de Sigmund Freud (Vol. 19, pp. 15-121). Rio de Janeiro: Imago. (Trabalho original publicado em 1923a)

Freud, S. (1996). A organização genital infantil: uma interpolação na teoria da sexualidade. In Edição standard das obras completas de Sigmund Freud (Vol. 19, pp. 155-163). Rio de Janeiro: Imago. (Trabalho original publicado em 1923b)

Freud, S. (1996). A dissolução do complexo de Édipo. In Edição standard das obras completas de Sigmund Freud (Vol. 19, pp. 191-193). Rio de Janeiro: Imago. (Trabalho original publicado em 1924)

Freud, S. (1996). Algumas conseqüências psíquicas da distinção anatômica entre os sexos. In Edição standard das obras completas de Sigmund Freud (Vol. 19, pp. 273287). Rio de Janeiro: Imago. (Trabalho original publicado em 1925)

Freud, S. (1996). Sexualidade Feminina. In Edição standard das obras completas de Sigmund Freud (Vol. 21, pp. 231-253). Rio de Janeiro: Imago. (Trabalho original publicado em 1931)

Freud, S. (1996). Conferência XXXIII: feminilidade. In Edição standard das obras completas de Sigmund Freud (Vol. 22, pp. 113-134). Rio de Janeiro: Imago. (Trabalho original publicado em 1933)

Herrera, H. (2004). Frida: una biografía de Frida Kahlo. México: Editorial Diana. 
Jones, E. (1989). A vida e a obra de Sigmund Freud (Vol. 2). Rio de Janeiro: Imago. (Trabalho original publicado em 1955)

Kahlo, F. (1996). O diário de Frida Kahlo. Rio de Janeiro: José Olympio.

Kahlo, F. (2002). Cartas apaixonadas de Frida Kahlo. Rio de Janeiro: José Olympio.

Lacan, J. (1995). O seminário. Livro 4: a relação de objeto. Rio de Janeiro: Jorge Zahar. (Trabalho original publicado em 1956-1957)

Lacan, J. (1998). Escritos. Rio de Janeiro: Jorge Zahar.

Lacan, J. (1999). O seminário. Livro 5: as formações do inconsciente. Rio de Janeiro: Jorge Zahar. (Trabalho original publicado em 1957-1958)

Safatle, V. (1997). O amor pela superfície: Jacques Lacan e o aparecimento do sujeito descentrado. Tese de mestrado, Departamento de Filosofia, Letras e Ciências Humanas, Universidade de São Paulo, São Paulo.

Renata Wirthmann G. Ferreira, Psicanalista; Professora do Departamento de Psicologia do Campus de Catalão da Universidade Federal de Goiás (UFG). Doutoranda do programa de Pós-graduação em Psicologia Clínica e Cultura da Universidade de Brasília (UnB). Endereço de correspondência: Rua Ozório Vieira Leite, 63. CEP 75703280 - Catalão/GO. Endereço eletrônico: rewgferreira@uol.com.br

Tania Rivera, Psicanalista; Professora do Departamento de Psicologia Clínica e Cultura da Universidade de Brasília (UnB); Doutora em Psicologia (Université Catholique de Louvain, Bélgica); Pesquisadora Bolsista do CNPq. Endereço de correspondência: SHIS QI 23/ Chácara 16 - CEP 71660-730 - Brasília/DF. Endereço eletrônico: taniarivera@ uol.com.br

Recebido em: 9/09/2007

Aceito em: 14/05/2008 